\title{
Use sulfoferritic cements in construction
}

\author{
Svetlana V. Samchenko ${ }^{1}$ and Dmitriy A. Zorin ${ }^{1, *}$ \\ ${ }^{1}$ Moscow State University of Civil Engineering, Yaroslavskoe shosse, 26, Moscow, 129337, Russia
}

\begin{abstract}
Currently, high-rise construction has received increasing attention around the world. In the big cities under construction is less space and one solution is the high-rise construction. However, high-rise buildings use special requirements, such as strength, thermal insulation, wind load and others. When concrete is exposed to continuous loads by wind or to mechanical loads, it undergoes abrasion. Resistance to this process depends on the characteristics of materials that the concrete and finishing seams are made of. Research on increasing impact and abrasion resistance of calcium sulfoferrite-based cement stone from the perspective of formation of cement stone structure will be instrumental in developing durable materials for application in high-rise construction.
\end{abstract}

\section{Introduction}

To ensure permanent integrity of a structure is an engineer's primary goal. Therefore, a high-rise construction is constructed taking into account wind loads and the way they influence buildings integrity, wind noise, thermal insulation and also the materials used in this construction.

Wind load is viewed as the most critical load among temporary loads on high-rise construction. This is due to the fact that using steel and reinforced concrete elements with light-weight re-bars and fillers in multistory construction has resulted in reduced buildings weight and has eliminated restrictions for structures height. Implementing new materials and construction methods has led to a significant reduction in structural stiffness, hence today wind loads have started to be of vital importance in construction [1].

Wind loads imply not only exposure to strong winds but also take into account the movement of air masses with different moisture and temperature carrying large amounts of solid particles. That is why the choice of building materials for high rise construction is limited not only by their technological features, but also by their ability to withstand chemical and physical exposure factors [2].

Erosion, or weathering, is caused by wind, water, and icing, and results in loss of material off the concrete surface and chipping. As concrete is a brittle material, the edges of joints and seams are fractured by impacts. When concrete is exposed to continuous loads by solid particles or to mechanical loads, it undergoes abrasion. Resistance to this process depends on the characteristics of materials that the concrete and finishing seams are made of.

\footnotetext{
* Corresponding author: dim-z@yandex.ru
} 
In constructions exposed to weather carbon dioxide results in formation of calcium carbonate. In hydraulic structures, its presence in the composition of water produces leaching that mainly affects binding materials $[3,4]$.

Concrete leaching is a similar process, with the exception that it develops in the presence of moisture and consists in removal of cement stone. Degradation intensifies under the impact of water that contains carbon dioxide, or a sulphuric acid of organic origin [5].

Physical factors of concrete degradation include its shrinkage, both plastic and drying shrinkage, that results in formation of micro-cracks, cracks or warping. This is especially true for materials used to seal joints and seams. At present, there is a record of using expanding admixtures for sealing joints during metro tunneling where these materials are used for joint packing and manufacturing of tubings [6-8].

Much attention is devoted to the problem of concrete corrosion damage. Researchers explore opportunities to increase resistance of cement formulations by using various types of binding materials, as well as by introducing corrosive-resistance aggregates and fillers into their composition [9-12].. Researches have been completed on corrosion resistance of cement stone with sulfate-bearing clinkers [13-16]. Hence, research on increasing impact and abrasion resistance of calcium sulfoferrite-based cement stone from the perspective of formation of cement stone structure will be instrumental in developing durable materials for application in high-rise construction.

Calcium sulfoferrite-based cements are capable of not only compensating for shrinkage but also of leading to system expansion. Besides, these cements are characterized by high strength properties $[8,17,18]$.

This study is aimed at obtaining a calcium sulfoferrite-based binding material having nonshrinking properties and resistant to abrasion and impacts.

\section{Materials and methods}

In the study, binding material was obtained using sulfoferrite clinker (SFC) and Portland cement clinker (OPC). Clinkers physical properties and chemical analysis are given in Table 1. Mineralogical composition of cements is listed in Table 2.

Table 1. Physical and chemical properties of cements and sulfoferrite clinker.

\begin{tabular}{|c|c|c|}
\hline & OPC & SFC \\
\hline Specific gravity & 3.16 & 2.96 \\
\hline Blaine fineness, cm cm $^{2}$ & $2700(3500)$ & 4230 \\
\hline Loss of ignition, \% & 0.21 & 0.01 \\
\hline $\mathrm{SiO}_{2}, \%$ & 22.03 & 12.23 \\
\hline $\mathrm{Al}_{2} \mathrm{O}_{3}, \%$ & 5.15 & 3.09 \\
\hline $\mathrm{CaO}, \%$ & 65.41 & 51.83 \\
\hline $\mathrm{MgO}, \%$ & 1.20 & 1.92 \\
\hline $\mathrm{SO}_{3}, \%$ & 0.34 & 5.19 \\
\hline $\mathrm{Fe}_{2} \mathrm{O}_{3}, \%$ & 4.86 & 23.79 \\
\hline
\end{tabular}

Binding material was obtained by replacing a part of Portland cement clinker with sulfoferrite clinker powder. Portland cement clinkers were ground to Blaine specific surface area of $2700 \mathrm{~cm}^{2} / \mathrm{g}$ and $3500 \mathrm{~cm}^{2} / \mathrm{g}$. Calcium sulfate dihydrate was ground separately to specific surface area of $3500 \mathrm{~cm}^{2} / \mathrm{g}$. Sulfoferrite clinker powder was ground to fractions of: $>80 \mu \mathrm{m}, 63-80 \mu \mathrm{m}, 45-63 \mu \mathrm{m}, 28-45 \mu \mathrm{m}$ and less than $28 \mu \mathrm{m}$. The mixtures were prepared by mixing components together in the following ratio: PC clinker $-80 \%$, expanding admixture (of a certain fraction) $-10 \%$, and gypsum $-10 \%$. Finished cements were mixed with water 
at the $\mathrm{w} / \mathrm{c}$ ratio $=0.4$. Cement paste was formed into specimen hardened under normal conditions for $1,3,7,14$ and 28 days. Then the samples were tested for strength and expansion, as well as went through physical and chemical analysis. Strength tests were conducted in compliance with GOST 30744-2001 [21]. Abrasion tests were conducted in compliance with GOST 13087-81 [22]. Formation of cement stone structure of binding material was studied using scanning electron microscopy (SEM).

Table 2. Mineralogical composition of cements

\begin{tabular}{|c|c|c|}
\hline & OPC & SFC \\
\hline Alite & 67 & - \\
\hline Belite & 8 & 25 \\
\hline Tricalcium aluminate & 5 & - \\
\hline Calcium aluminoferrite & 13 & - \\
\hline Calcium sulfoferrite & - & 75 \\
\hline
\end{tabular}

The study focused on how expanding component dispersity affects the morphology of ferrous ettringite formation and the properties of binding material. To eliminate the influence of gypsum dispersity, the samples were mixed with saturated gypsum solution. After that they were hardened for 6, 12 and 24 hours, as well as for 3, 7, 14 and 28 days, and were studied using a variety of physical and chemical methods. The quantity of formed ferrous ettringite was determined using the chemical method described in the monograph [19]. Simultaneously, studies were conducted on microslides using optical microscopy and X-ray phase analysis.

\section{Results}

\subsection{Effect of expanding component dispersity on the morphology of ferrous ettringite}

The effect of expanding component dispersity on the morphology of ferrous ettringite formation was studied using the minerals of sulfate-bearing clinkers $2 \mathrm{CaOFe}_{2} \mathrm{O}_{3} 0.8 \mathrm{CaSO}_{4}$. For the study, it was ground to fractions of: $>80 \mu \mathrm{m}, 63-80 \mu \mathrm{m}, 45-63 \mu \mathrm{m}, 28-45 \mu \mathrm{m}$ and less than $28 \mu \mathrm{m}$. To eliminate the influence of gypsum dispersity, the samples were mixed with saturated gypsum solution. After that they were hardened for 6, 12 and 24 hours, as well as for 3, 7, 14 and 28 days, and were studied using a variety of physical and chemical methods.

The results of experiments revealed that the smaller the size of initial hydrating grains of the $2 \mathrm{CaOFe}_{2} \mathrm{O}_{3} 0.8 \mathrm{CaSO}_{4}$ mineral, the faster its hydration occurs, which is evidenced by the growth of hydration degree as shown by the data of X-ray phase analysis. Measurement results are given in Table 3.

Calcium sulfoferrite $2 \mathrm{CaOFe}_{2} \mathrm{O}_{3} 0.8 \mathrm{CaSO}_{4}$ is characterized by low hydration activity which is confirmed by slow liquid phase saturation with calcium ions and slow growth of medium $\mathrm{pH}$ factor. For hydration of the less than $28 \mu \mathrm{m}$ fraction, the maximum value of $\mathrm{pH}$ $=13.5$ is reached in 24 hours (Fig. 1). At the same time, a higher amount of formed crystals is observed in the same fraction (Fig. 2). 


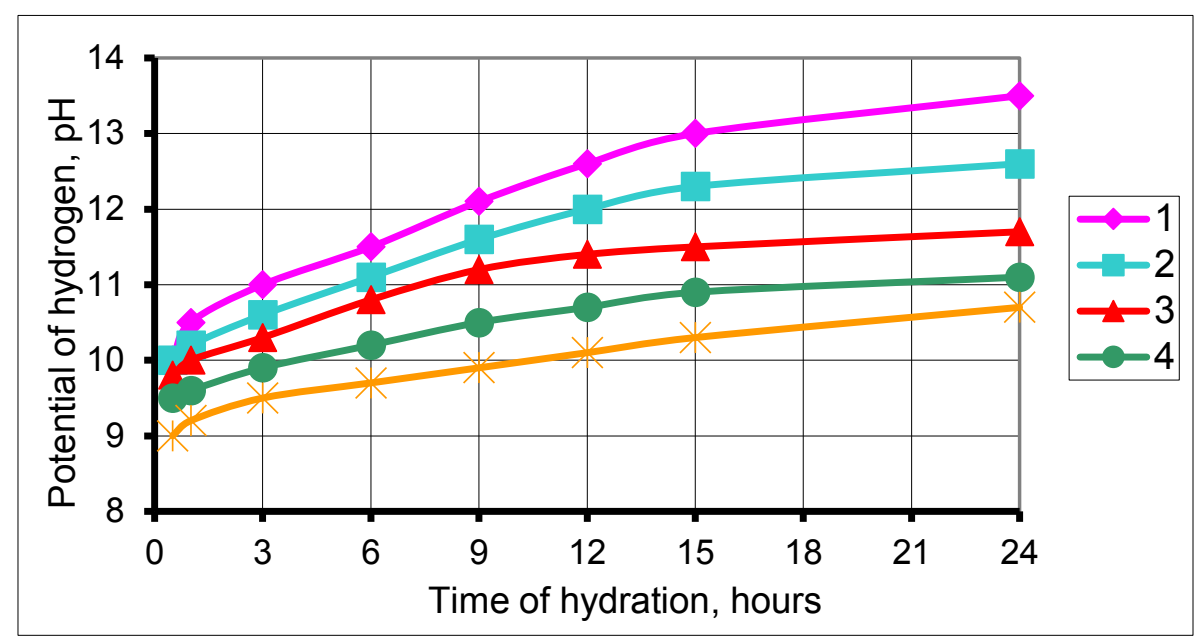

Fig. 1. Medium $\mathrm{pH}$ variation during hydration of $2 \mathrm{CaOFe} 2 \mathrm{O} 30.8 \mathrm{CaSO} 4$ different fractions $(1$ - fractions less than $28 \mu \mathrm{m}, ; 2-28-45 \mu \mathrm{m} ; 3-45-63 \mu \mathrm{m} ; 4-63-80 \mu \mathrm{m} ; 5->80 \mu \mathrm{m})$.

Table 3. The characteristic of the process of $2 \mathrm{CaOFe}_{2} \mathrm{O}_{3} 0.8 \mathrm{CaSO}_{4}$ mineral hydration for different fractions.

\begin{tabular}{|c|c|c|c|}
\hline $\begin{array}{c}\text { Grain } \\
\text { size, } \\
\boldsymbol{\mu m}\end{array}$ & $\begin{array}{c}\text { Time of } \\
\text { hydration, days }\end{array}$ & $\begin{array}{c}\text { Degree of hydration } \\
\text { (X-ray), \% }\end{array}$ & $\begin{array}{c}\text { Amount of ferrous } \\
\text { ettringite }\end{array}$ \\
\hline \hline \multirow{4}{*}{$<28$} & 0,25 & 12,3 & 14,8 \\
\cline { 2 - 4 } & 0,5 & 23,2 & 25,3 \\
\cline { 2 - 4 } & 1 & 26,8 & 28,2 \\
\hline \multirow{4}{*}{$28-45$} & 3 & 29,8 & 36,9 \\
\cline { 2 - 4 } & 0,25 & 11,6 & 13,5 \\
\cline { 2 - 4 } & 0,5 & 21,6 & 23,9 \\
\cline { 2 - 4 } & 1 & 25,6 & 29,5 \\
\hline \multirow{3}{*}{$45-63$} & 3 & 28,8 & 36,1 \\
\cline { 2 - 4 } & 0,5 & 18,4 & 13,1 \\
\cline { 2 - 4 } & 1 & 21,3 & 24,1 \\
\hline \multirow{4}{*}{$63-80$} & 3 & 30,5 & 37,3 \\
\cline { 2 - 4 } & 0,5 & 14,8 & 11,5 \\
\cline { 2 - 4 } & 1 & 18,9 & 12,5 \\
\hline \multirow{4}{*}{$>80$} & 3 & 24,2 & 32,2 \\
\cline { 2 - 4 } & 7 & 30,8 & 37,7 \\
\cline { 2 - 4 } & 1 & 7,1 & 7,7 \\
\cline { 2 - 4 } & 3 & 8,3 & 9,2 \\
\cline { 2 - 4 } & 7 & 15,0 & 12,9 \\
\hline
\end{tabular}

The study of hydration processes of calcium sulfoferrite mineral with the composition of $2 \mathrm{CaOFe}_{2} \mathrm{O}_{3} 0.8 \mathrm{CaSO}_{4}$ in microslides demonstrated that hydration of small-size mineral fractions (less than $28 \mu \mathrm{m}$ ) occurs at the time of its partial dissolution along with crystallization of short prismatic crystals $(l=50-60 \mu \mathrm{m}, d=5-6 \mu \mathrm{m})$. Moreover, in small-size fractions $(28-45$ and less than $28 \mu \mathrm{m})$ formation of such crystals around initial mineral grains 
begins as early as in 24 hours, in 45-63 fractions it occurs at the age of 3 days, whereas in large-size fractions $(63-80$ and $>80 \mu \mathrm{m})$ it occurs only by the 14 th day.

Formation of ferrous ettringite prismatic crystals always occurs regardless of the fraction of mineral $2 \mathrm{CaOFe}_{2} \mathrm{O}_{3} 0.8 \mathrm{CaSO}_{4}$. The mineral's dispersity affects only its hydration activity. Smaller-size fractions hydrate faster, while medium-size and coarse fractions are very slow to hydrate due to low hydration activity. Formation of ferrous ettringite prismatic crystals is observed only at the age of 7-14 days.

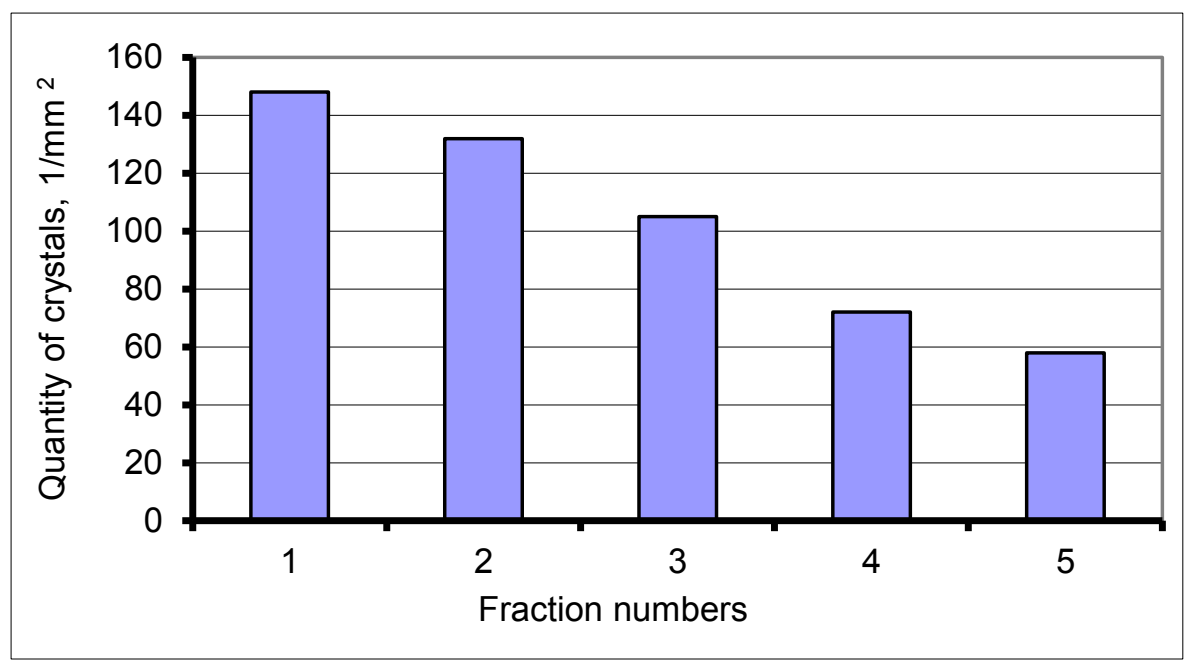

Fig. 2. Initially formed crystals per $1 \mathrm{~mm}^{2}$ of microscope slide for hydration within 24 hours of $2 \mathrm{CaOFe}_{2} \mathrm{O}_{3} 0.8 \mathrm{CaSO}_{4}$ different fractions (fraction numbers as indicated in Fig. 1).

As obtaining a mono-sized composition of expanding admixture is hardly possible in the field conditions, experiments were conducted to study the influence of poly-sized composition of $2 \mathrm{CaOFe}_{2} \mathrm{O}_{3} 0.8 \mathrm{CaSO}_{4}$ mineral on the morphology of formed ettringite crystals.

Poly-sized mineral compositions were prepared by mixing of fine and coarse fractions with the ratio of $1: 1$. Less than $28 \mu \mathrm{m}$ and $28-45 \mu \mathrm{m}$ fractions of the $2 \mathrm{CaOFe}_{2} \mathrm{O}_{3} 0.8 \mathrm{CaSO}_{4}$ mineral were selected, as these fractions demonstrate the most intensive hydration within the first 24 hours. This choice of fractions was made because in the first hours of hydration smallsize fractions saturate the liquid phase very quickly, contributing to formation of large numbers of crystallization centers. On the contrary, coarse fractions gradually saturate the liquid phase, and its ions should be used in crystals formation.

The obtained data revealed that the quantity of ferrous ettringite in the first hours and days of hydration is somewhat lower than in small-size fractions, but still higher that in largesize fractions, if compared to the quantity formed in mono-sized compositions.

\subsection{Effect of expanding component dispersity on formation of cement stone structure.}

Cement stone structure mainly depends on the quantity of hydrates and porosity. It widely varies depending on composition and crystallinity degree of crystalline hydrates which, in turn, depends on factors such as impurities presence in minerals, hardening conditions, as well as hardening system dispersity $[16,20]$. 
To study the influence of expanding component dispersity on cement stone formation, Portland cement was mixed with different fractions of calcium sulfoferrite expanding component (less than $28 \mu \mathrm{m}, 28-45,45-63,63-80$ and over $80 \mu \mathrm{m}$ fractions).

Portland cement clinker was ground to Blaine specifics surface areas of 2700 and $3500 \mathrm{~cm} 2 / \mathrm{g}$. Calcium sulfate dihydrate was ground separately to specific surface area of $3500 \mathrm{~cm} 2 / \mathrm{g}$. The mixtures were prepared by mixing components together in the following ratio: PC clinker $-80 \%$, expanding admixture (of a certain fraction) $-10 \%$, and gypsum $10 \%$. Finished cements were mixed with water at the $\mathrm{w} / \mathrm{c}$ ratio $=0.4$. Cement paste was formed into specimen that fastened under normal conditions for 1, 3, 7, 14 and 28 days. Then the samples were tested for strength and expansion. Obtained results are given in Table 3 and Figure 3.

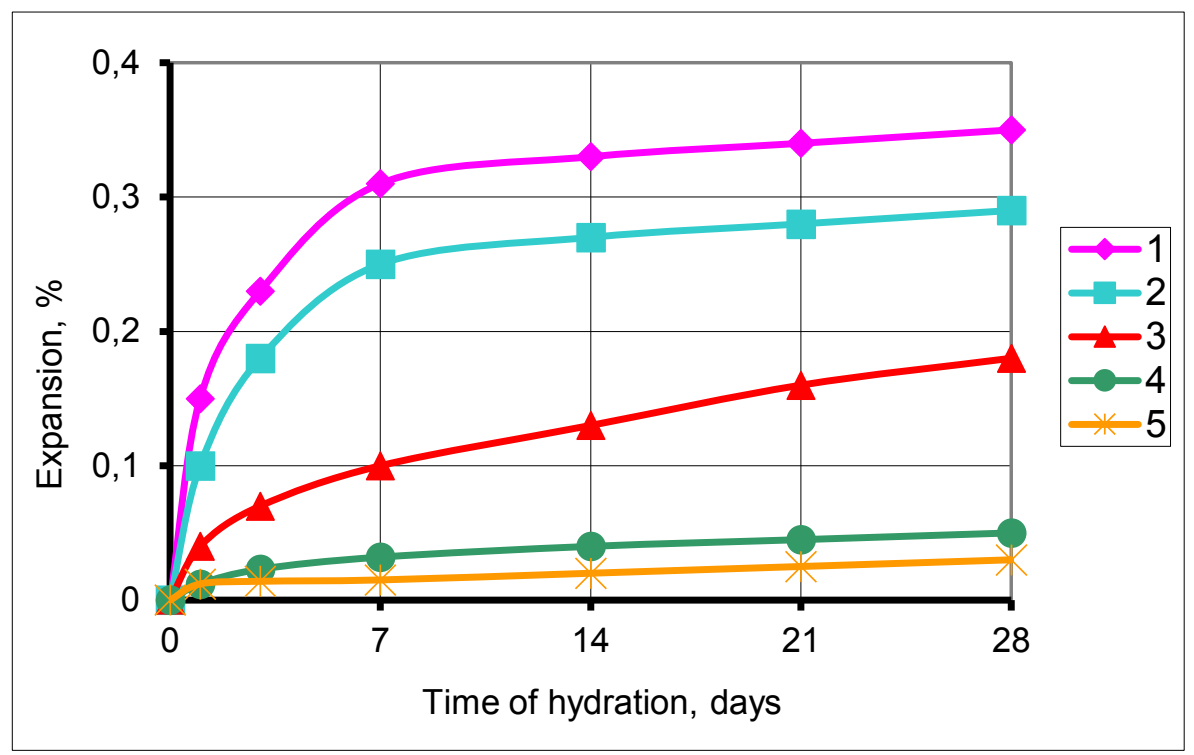

Fig. 3. Expansion of produced cement with expansive admixture and gypsum. fraction numbers as indicated in Fig. 1

Table 4. Strength and self-stressing of mixed cements for different fractions.

\begin{tabular}{|c|c|c|c|c|c|c|c|c|}
\hline \multirow{3}{*}{$\begin{array}{c}\text { Grain size, } \\
\mu \mathrm{m}\end{array}$} & \multicolumn{4}{|c|}{ Mixed cement with $S=2700 \mathrm{~cm}^{2} / \mathrm{g}$} & \multicolumn{4}{|c|}{$\begin{array}{l}\text { Mixed cement with } S=3500 \\
\mathrm{~cm}^{2} / \mathrm{g}\end{array}$} \\
\hline & \multicolumn{2}{|c|}{ Strength, $\mathrm{MPa}$} & \multicolumn{2}{|c|}{$\begin{array}{c}\text { self-stressing, } \\
\mathrm{MPa}\end{array}$} & \multicolumn{2}{|c|}{ Strength, MPa } & \multicolumn{2}{|c|}{$\begin{array}{c}\text { self-stressing, } \\
\mathrm{MPa}\end{array}$} \\
\hline & 1 day & $\begin{array}{c}28 \\
\text { days }\end{array}$ & 1 day & 28 days & 1 day & $\begin{array}{c}28 \\
\text { days }\end{array}$ & 1 day & $\begin{array}{c}28 \\
\text { days }\end{array}$ \\
\hline$<28$ & 15 & 58 & 0,48 & 1,5 & 18 & 61 & 0,6 & 1,8 \\
\hline $28-45$ & 14,8 & 56 & 0,44 & 1,3 & 17 & 59 & 0,55 & 1,6 \\
\hline $45-63$ & 14,2 & 53 & 0,41 & 1,12 & 15 & 57 & 0,5 & 1,5 \\
\hline $63-80$ & 12,5 & 51 & 0,32 & 0,96 & 13 & 54 & 0,4 & 1,3 \\
\hline$>80$ & 10,6 & 44 & 0,08 & 0,9 & 11 & 48 & 0,1 & 1,2 \\
\hline
\end{tabular}

The strongest expansion was observed in samples that contain small-size fractions of SFC minerals, as their hydration occurs more intensely that hydration of coarse fractions of the minerals. Expansion relationships in ORC-based cements with different specific surface areas $\left(2700\right.$ and $\left.3500 \mathrm{~cm}^{2} / \mathrm{g}\right)$ were almost identical (Fig. 3). Furthermore, a less porous 
stone structure is formed that ensures high strength of samples, and if expansion is restricted, it also ensures self-stressing of the stone. Notably, the best results are obtained in combination with Portland cement clinker ground to specific surface area of $S=3500 \mathrm{~cm}^{2} / \mathrm{g}$. (Table 4).

According to the data of electron microscopy studies, formation of cement stone structure with finely-ground Portland cement clinker and fine fraction of calcium sulfoferrite is caused by formation of ferrous ettringite prismatic crystals and by finely-crystalline gelatine mass of calcium silicate hydrates.

Conducted studies reveal that grinding fineness and particle size distribution of cement produce a strong impact on formation of cement stone structure. Furthermore, dispersity of both the Portland cement component, and the expanding component is significant.

Increasing the fineness of Portland cement grinding with the permanent fraction of expanding component results in higher cement strength. The effect of expansion depends both on the fineness of expanding component, and on its type.

In case of calcium sulfoferrite-based expanding component, the strongest expansion effect is produced when the component is introduced into cement in small-size fractions $(<28 \mu \mathrm{m}$ and $28-45 \mu \mathrm{m})$. Their hydration accelerates both due to increased reacting surface of particles, and their activity. Higher hydration activity of small-size particles ensures that formation of cement stone non-shrinking structure accelerates, while fast hydration of finelyground Portland cement component contributes to compaction of cement stone structure and increase of its strength.

\subsection{Resistance of calcium sulfoferrite-based cement stone to abrasion}

The above-mentioned studies demonstrate how a calcium sulfoferrite-based binding material with non-shrinking properties can be obtained. When hardened, this cement forms a strong and dense cement stone, and can ensure its resistance to abrasion if used for sealing joints and seams.

To confirm this assumption, tests were conducted on samples made from cements that contained calcium sulfoferrites. Obtained results are given in Table 5.

Table 5. Resistance to abrasion of mixed cement with calcium sulfoferrite.

\begin{tabular}{|l|l|l|l|}
\hline Consumption of cement, $\mathrm{kg} / \mathrm{m}^{3}$ & 400 & 425 & 450 \\
\hline Water-cement ratio & 0.45 & 0.42 & 0.40 \\
\hline $\begin{array}{l}\text { Weight loss (kg per } 1 \mathrm{~m}^{2} \text { of surface abrasion for 1 hour) } \\
\text { water-saturated samples }\end{array}$ & 0.55 & 0.48 & 0.30 \\
\hline
\end{tabular}

\section{Discussion}

The study of hydration in poly-sized compositions of $2 \mathrm{CaOFe}_{2} \mathrm{O}_{3} 0.8 \mathrm{CaSO}_{4}$ mineral demonstrated that small-size fractions ensure the formation of crystallization centers, while the less than $45 \mu \mathrm{m}$ particles, constantly interacting with the liquid phase, provide for gradual growth of crystals.

Conducted studies allow to conclude that for calcium sulfoferrite-based expanding admixtures it is preferable to use a poly-sized composition that combines only fine fractions $(<28 \mu \mathrm{m}$ and $28-45 \mu \mathrm{m})$.

To produce expanding cements based on calcium sulfoferrite admixtures the best practice is to introduce these minerals in fine fractions. To obtain dense strong cement stone, Portland cement component should be ground to specific surface area of at least $3000 \mathrm{~cm}^{2} / \mathrm{g}$. 
The results demonstrate that samples made from cements containing calcium sulfoferrites are characterized by resistance to abrasion. Hence, they can be recommended for using in structures exposed to increased physical impacts.

\section{Conclusion}

As a result of conducted studies, the following conclusions can be made:

1. Formation of ferrous ettringite prismatic crystals always occurs regardless of the fraction of mineral $2 \mathrm{CaOFe}_{2} \mathrm{O}_{3} 0.8 \mathrm{CaSO}_{4}$. The mineral's dispersity affects only its hydration activity. Smaller-size fractions hydrate faster, while medium-size and coarse fractions are very slow to hydrate due to low hydration activity. Formation of ferrous ettringite prismatic crystals is observed only at the age of 7-14 days.

2. During hydration in poly-sized compositions of $2 \mathrm{CaOFe}_{2} \mathrm{O}_{3} 0.8 \mathrm{CaSO}_{4}$ mineral small-size fractions of less than $28 \mu \mathrm{m}$ ensure formation of crystallization centers, while particles of 28 to $45 \mu \mathrm{m}$, constantly interacting with the liquid phase, provide for gradual growth of crystals.

3. To produce calcium sulfoferrite-based expanding additives it is preferable to use a polysized composition that combines only fine fractions $(<28 \mu \mathrm{m}$ and $28-45 \mu \mathrm{m})$.

4. Formation of cement stone structure with finely-ground Portland cement clinker and fine fraction of calcium sulfoferrite is caused by formation of ferrous ettringite prismatic crystals and by finely-crystalline gelatine mass of calcium silicate hydrates.

5. Calcium sulfoferrite-based binding materials, having a high strength and an ability to expand, as well as to form cement stone resistant to abrasion, may be used in high-rise construction as a material for joints and seams sealing.

\section{References}

1. Osobennosti otsenki vetrovogo vozdeystviya na vysotnye zdaniya, Youth science forum: Technical and mathematical Sciences, Moscow, 1 (30) (2016).

2. S.V. Samchenko, Sul'foalyumoferritnye tsementy, svoystva i primenenie/ Beton i zhelezobeton, Sbornyy zhelezobeton, 1 (10) 18-21 (2014)

3. S.V. Samchenko, T. V. Kouznetsova, Resistance of the calcium sulphoaluminate phases to carbonation, Cement, Wapno, Beton. 5, 317-322 (2014)

4. T. V. Kouznetsova, et al., Carbonation of the constituents of hydrated Portland cement, aluminate and sulphoaluminate cements, 13 Int. Baustofftagung, Ibausil, Weimar, Bundesrepublik Deutschland, 2, 2-0543-2-0546.

5. P. Hou, R. Zhang, Y. Cai, X. Cheng, S. P. Shah Construction and Building Materials, 113, 890-896 (2016)

6. T.V.Kouznetsova, et al., The use shrinkage-compensating cements in metro building/ 12th International Congress on the Chemistry of Cement (ICCC). Montreal, Canada, pst. 5.07 (2007)

7. T. V. Kouznetsova, et al., Modifitsirovanie portlandtsementa dlya ustraneniya usadki betona, Tsement i ego primenenie, 14-15 (2007)

8. S.V. Samchenko, Sul'fatirovannye alyumoferrity kal'tsiya i tsementy na ikh osnove, (Moscow, 2004)

9. A.S. Brykov, et al., Sul'fatostoykost' portlandtsementnogo kamnya s alyumosoderzhashchimi uskoritelyami skhvatyvaniya, Tsement i ego primenenie, $\mathbf{5}$, 59-63 (2013) 
10. G.S. Royak, et al., Shlakoportlandtsement dlya predotvrashcheniya korrozii betona, Tsement i ego primenenie, 3, 104-106 (2011)

11. K.B. Safarov, V.F. Stepanova, Regulirovanie reaktsionnoy sposobnosti zapolniteley i povyshenie sul'fatostoykosti betonov putem sovmestnogo primeneniya nizkokal'tsievoy zoly-unosa i vysokoaktivnogo metakaolina Stroitel'nye materialy. 5. 70-73 (2016)

12. L.Ya. Kramar et al., Betony vysokoy sul'fatostoykosti, Tsement i ego primenenie. 4. 127-131 (2011)

13. S.V. Samchenko, O.V. Zemskova, D.A. Zorin Corrosion resistance of sulfated cements in carbonate and in carbonate-sulfate mediums, MATEC Web of Conferences 106, 03014 (2017).

14. S.V. Samchenko, Yu. R. Krivoborodov, Vlijanie dispersnosti special'nogo cementa na strukturu tverdejushhego kamnja, Vestnik Belgorodskogo gosudarstvennogo tehnologicheskogo universiteta im. V.G. Shuhova. 2/5. 238-240 (2003)

15. A.P. Osokin, Yu. R. Krivoborodov, Svojstva rasshirjajushhihsja cementov i ih primenenie, Cement i ego primenenie. 6. 43 (2004)

16. S.V. Samchenko, et al., Influence of fineness of expansive components of cement properties, Cement-Wapno-Beton, XIII/LXXV, 5, 254-257 (2008)

17. Yu. R. Krivoborodov, S.V. Samchenko, Fiziko-khimicheskie svoystva sul'fatirovannykh klinkerov ( Tsementnaya promyshlennost', Moscow, 1991)

18. I.N. Borisov, et al., Sintez sul'foferritnogo klinkera dlja proizvodstva bezusadochnyh i rasshirjajushhihsja cementov. Sovremennye problemy nauki i obrazovanija, 2, 269 (2012).

19. S.V. Samchenko, Rol' jettringita v formirovanii i genezise struktury kamnja special'nyh cementov (RHTU im D.I. Mendeleeva, Moscow, 2005)

20. S.V. Samchenko, Formirovanie i genezis struktury tsementnogo kamnya (Moscow, 2016)

21. Russian Standard GOST 30744-2001 CEMENTS Methods of testing with using polyfraction standard san.

22. Russian Standard GOST 13087-81 Concretes. Methods for determination of abrasion. 